venientes del campo de las Ciencias Cognitivas, y de usarlas en defensa del argumento central del libro.

También es muy de agradecer el esfuerzo hecho por los autores por desarrollar una filosofía de la ciencia historicista que no renuncie de entrada a dar cuenta de la estructura normativa de la ciencia. Su estrategia de localizar dicha estructura en las normas implícitas en las diversas prácticas que conforman el quehacer científico resulta atractiva, además, por cuanto da una respuesta clara a la cuestión del origen de la normatividad de la ciencia.

Se echan de menos, si acaso, más detalles acerca de las soluciones ofrecidas en los capítulos seis, siete y ocho a los problemas de la unidad de la ciencia, de la abstracción y del cambio científico. Aunque las soluciones ofrecidas a estos tres problemas resultan atractivas en sí mismas, en ocasiones no está del todo claro la forma en que éstas se siguen de las definiciones de práctica y de heurística ofrecidas en los capítulos cuatro y cinco. En ocasiones no queda claro, en otras palabras, cuál es el papel exacto que los detalles del marco teórico desarrollado en la primera parte del libro juegan a la hora de sustentar las soluciones ofrecidas en los tres últimos capítulos.

En cualquier caso, la propuesta ofrecida por Sergio Martínez y Xiang Huang resulta muy digna de estima no sólo por las conclusiones que se alcanzan en el libro, sino también por las muchas otras direcciones en las que este enfoque podría extenderse. La filosofía de la ciencia centrada en prácticas desarrollada por los autores, en efecto, proporciona un marco teórico que promete ser extremadamente fértil en su aplicación a problemas filosóficos de toda índole. En este sentido, sería de especial interés aplicar la noción de práctica ofrecida por los autores para dar cuenta de la naturaleza del teorizar científico y, en última instancia, de la naturaleza del conocimiento teórico. Es una virtud de este concepto de práctica, ciertamente, el ser lo suficientemente flexible como para poder acometer este tipo de reto.

Pablo Ruiz de Olano

University of Notre Dame pruizdeo@nd.edu

BIBLID 0495-4548(2017)32:3p.390-392

DOI: $10.1387 /$ theoria.18065

Alvaro Moreno and Matteo Mossio. 2015. Biological autonomy: a philosophical and theoretical enquiry. Dordrecht: Springer.

In recent years, an increasing number of philosophers have argued that the key to understanding life lies in understanding its organisation; that living organisms must be studied as whole systems rather than as a decomposed collection of mechanistic parts. But what defines biological organisation? How is it distinguished from the organisation of simpler physical systems? How does it relate to complex psychological systems? Mossio \& Moreno's 2015 book, Biological Autonomy, is a sustained and thorough attempt to answer these questions. The book surmises, synthesizes and elaborates on the work of a number of philosophers, including Barandiaran, Bich, Etxeberria, Juarrero, Montevil, Moreno, Mossio, RuizMirazo, Saborido and Umerez; many of whom have been working in collaboration for 
upwards of twenty years. Biological Autonomy provides a snapshot of the ideas which have emerged out of these collaborations.

The book is described as both a theoretical and philosophical enquiry. On the theoretical side, insights are synthesized from a number of theoretical biologists including Maturana \& Varela, Kauffman, Pattee, Ganti and Rosen; and links are drawn to other contemporary accounts of biological autonomy, most notably the account developed by Hooker, Christensen \& Bickhard. As a result, many of the ideas are not entirely new, but their synthesis provides the reader with a useful introduction to the various milestones which have shaped current organisational theories. The novel contributions of the book center around the clarification of various concepts, most notably closure and constraint; the identification of two distinct dimensions of biological autonomy - the constitutive and the interactive; and the demonstration of how these concepts can be usefully applied to various types of biological phenomena; including single-cellular and multi-cellular organisms, ecosystems, lineages and cognition. Philosophically, Mossio \& Moreno then endeavour to show how their theory of biological organisation as a closure of constraints can inform traditional philosophical issues, such as the nature of biological causation and functions. In this review, we provide a brief overview of their theoretical contributions and some discussion of Mossio \& Moreno's claim that biological organisation can naturalise the normative and teleological dimensions of biological functions.

\section{Biological organisation as a closure of constraints}

The core ambition of Biological Autonomy is to provide an account of the organisation of biological systems, elucidating how it differs from the organisation of other physical systems. At the heart of Mossio \& Moreno's project lies an appeal to the closed causal structure of biological systems, which they characterize as self-determining. This structure forms between entities, defined not by their physical characteristics but by their role in a system. Specifically, it is claimed, these entities play a constraining role. To understand what is meant by the term constraint, Mossio \& Moreno offer the example of a ball sitting on a sloping plane (5). The slope of the plane acts as a boundary condition constraining the possible dynamics of the ball that rests on it. The slope of the plane is not, however, changed by the way the ball rolls across its surface. Which is to say, what the ball does is dependent on the slope but what the slope does is not dependent on the ball. There is a one-way dependency relation. In this example, the slope is a constraint and the ball is not. In a biological system, the relations between constituents are much more complex. Specifically, entities in biological systems are mutually dependent. This does not mean that every component of a biological system will directly constrain the activity of every other component in the biological system. But it requires that every component of a biological system engage in at least two dependency relations. In one of those relations, another component of the biological system must be dependent on it. Which is to say it must play the role of a constraint. In the second of those relations, it must be dependent on another biological component. Which is to say, it must be constrained. The nature of dependency is also different between physical and biological systems. While the dynamics of the ball might depend on the slope, its existence does not. By contrast, constraints in biological systems are dependent on each other for their generation and regeneration. In identifying all of the components that fit these crite- 
ria, you identify the components of a biological system. In this way, Mossio \& Moreno's theory of biological organisation as a closure of constraints also offers a theory of biological individuation.

\section{Constitutive and interactive biological autonomy}

Having provided a theory of biological organisation as a closure of constraints, Mossio \& Moreno then turn to the question of biological autonomy, arguing that it is comprised of two dimensions. The first constitutive dimension requires that the system be a causally closed system. It emphasizes the fact that all biological systems are dissipative systems. Like all dissipative systems, their parts tend to decay over time and must be continuously regenerated if they are to continue to exist. In order to maintain the organisation of which they are part and on which they depend, constraints harness energy and matter from the thermodynamic flow that surrounds them and channel it into the regeneration of the organisation. The second interactive dimension emphasizes the way biological systems interact with their environments in order to promote their own maintenance.

\section{Naturalising biological functions}

One of the core philosophical claims of Biological Autonomy is that the constitutive dimension of biological autonomy can naturalise function ascriptions. Specifically, Mossio \& Moreno claim to show that although 'functional statements cannot be reduced to ordinary causal ones, they are compatible with the structure of scientific discourse' (64). They approach the problem by conceptually decomposing functions into three dimensions - teleological, normative and organisational — and arguing that these dimensions can be grounded in the closure of constraints which defines the constitutive dimension of biological systems. More formally, they claim that functions must satisfy three jointly necessary and sufficient conditions: 'a trait $\mathrm{T}$ has a function if and only if:

$$
\begin{aligned}
& \mathrm{C}_{1} \text {. T exerts a constraint that contributes to the maintenance of the organisation } \mathrm{O} \text {; } \\
& \mathrm{C}_{2} \text {. T is maintained under some constraints of } \mathrm{O} \text {; } \\
& \mathrm{C}_{3} \text {. O realizes closure' (73). }
\end{aligned}
$$

The crux of their approach thus lies in an appeal to the mutual dependency relations which define biological systems: the trait causes an effect which contributes to the maintenance of the organisation $\mathrm{O}$; in turn, the trait is maintained by $\mathrm{O}$. The emphasis is on a causal loop: 'Asked why we have hearts, we can legitimately answer because they pump blood given that 'the heart is there because it pumps blood (otherwise the organism, and thus the heart, would disappear), and pumping blood is a consequence of the heart's being there' (Mossio \& Moreno, 73). To put it bluntly, if the heart stopped pumping blood, the organism would very quickly cease to exist, and so too would the heart itself. In this sense, it is correct to say that I have a heart because it pumps blood.

One of the curious things about their account is that while Mossio \& Moreno claim functions are teleological, normative and organisational, the three conditions they identify are not markedly normative. From the get-go, then, if the ambition is to provide an account 
of functions which is irreducibly normative, it seems hard to see how this will be achieved. And yet, Mossio \& Moreno do claim to have naturalised normativity. Specifically, they claim that:

self-maintenance grounds normativity. The activity of a self-maintaining system has an intrinsic relevance for itself, to the extent that its very existence depends on the constraints exerted through its own activity. Such intrinsic relevance generates a naturalised criterion for determining what norms the system is supposed to follow: the system must behave in a specific way, otherwise it would cease to exist (71).

The first problem with this account is the ambiguity assigned to words such as supposed and must. The gist of the approach seems to rest on a claim that biological systems must maintain their conditions of existence or they will cease to exist. But stated as such, the term must doesn't demand a normative interpretation at all. What seems to be meant is that if a system does not behave in a certain way, it will cease to exist. That is, we are simply dealing with a statement of fact about biological systems. But based on this, Mossio \& Moreno claim we can identify what the system is supposed to do. To make this jump from facts to norms, they appeal to the notion of intrinsic relevance.

This brings us to the second criticism which Mossio \& Moreno's account of normative functions seems vulnerable to. Mossio \& Moreno assert that the activity of a self-maintaining system has an intrinsic relevance for itself, but only to the extent that its own existence depends on that activity. But this suggests that what is actually relevant to the system is its existence and this raises a sleuth of questions. Does this assume that living systems have an interest in maintaining their existence? Does it require the additional assumption that existence is in some way valuable or good? Can this be justified by appealing to the constitutive organisation of the system?

In sum, it seems to us that Mossio \& Moreno's account of normative functions would benefit from work in two directions. First, the relationship between the normative and teleological aspects of biological functions could be made clearer. Second, the type of normativity at stake could use some clarification. Yet despite these challenges, or possibly because of them, Biological Autonomy is a must-read book for any philosopher interested in the debate on biological functions. There is no doubt that the ideas contained within will shape the direction of debate for years to come. The same can be said for any philosopher interested in the nature of biological organisation, autonomy, individuation and causation.

Louisa Jane Holt

University of Copenhagen qdv361@hum.ku.dk

Sune Holm

University of Copenhagen suneh@hum.ku.dk 